\title{
Wpływ mikrobioty jelitowej na występowanie zaburzeń psychicznych oraz chorób neurodegeneracyjnych
}

The effect of intestinal microbiota on the occurrence of mental disorders and neurodegenerative diseases

Magdalena Frej-Mądrzak*, Patrycja Kołodziej, Jolanta Sarowska, Agnieszka Jama-Kmiecik

Zakład Nauk Podstawowych, Uniwersytet Medyczny we Wrocławiu

Abstrakt

W artykule podsumowano aktualny stan wiedzy na temat zaleźności między składem mikrobioty jelitowej a występowaniem zaburzeń psychicznych i chorób neurodegeneracyjnych.

Patogeneza zaburzeń psychicznych oraz chorób neurodegeneracyjnych może mieć związek ze składem bioty bakteryjnej jelit. Komunikacja między jelitami a mózgiem jest możliwa za pośrednictwem osi jelitowo-mózgowej i odbywa się za pomocą mechanizmów endokrynnych, neuronalnych i immunologicznych.

Skład mikrobioty jelitowej człowieka w trakcie jego życia podlega fluktuacjom. Bakterie jelitowe pełnią wiele funkcji, które są korzystne dla zdrowia gospodarza. Pod wpływem czynników środowiskowych może wystąpić dysbioza jelitowa - stan zaburzenia jakościowego i ilościowego bioty bakteryjnej jelit.

Istnieją wyraźne różnice między składem mikrobioty jelitowej osób ze zdiagnozowanymi zaburzeniami psychicznymi a składem mikrobioty jelitowej osób zdrowych. W schorzeniach takich jak depresja, schizofrenia czy autyzm stwierdza się dysbiozę jelitową, której skutkiem jest zmniejszenie integralności bariery jelitowej, a następnie przemieszczenie do krążenia ogólnego drobnoustrojów oraz ich produktów.

U osób ze zdiagnozowanymi chorobami neurodegeneracyjnymi (choroba Alzheimera, Parkinsona) skład bioty bakteryjnej jelit jest odmienny w porównaniu do osób zdrowych. Wybrane typy bakterii, za pośrednictwem osi jelitowomózgowej, mogą wpływać na procesy zachodzące w mózgu.

Istnieją zależności między składem mikrobioty jelitowej a występowaniem zaburzeń psychicznych i chorób neurodegeneracyjnych u ludzi. Są związane przeważnie z występowaniem dysbiozy jelitowej oraz zespołu nieszczelnego jelita.

Słowa

mikrobiota jelitowa • oś jelitowo-mózgowa • dysbioza jelitowa・szlak kinureninowy•zaburzenia psychiczne • choroby neurodegeneracyjne

Otrzymano: 27.03.2020, Zaakceptowano: 07.07.2021

Abstract

The pathogenesis of mental disorders and neurodegenerative diseases may be related to the composition of gut microbiota. Communication between the intestines and the brain is possible through the gut-brain axis and takes place via endocrine, neuronal and immunological mechanisms.

Presented here is a summary of the current state of knowledge on the relationship between the composition of the gut microbiota and the occurrence of mental disorders and neurodegenerative diseases.

The composition of human gut microbiota during its life is subject to fluctuations. Gut bacteria perform many functions that are beneficial to the health of the host. Under the influence of environmental factors, gut dysbiosis may occur a state of qualitative and quantitative disturbance of gut bacterial biota.

There are clear differences between the composition of the gut microbiota of people diagnosed with mental disorders and the composition of the gut microbiota of healthy people. In such conditions as depression, schizophrenia or autism, intestinal dysbiosis is observed, which compromises the integrity of the intestinal barrier, followed by the displacement of microorganisms and their products into the general circulation.

In people diagnosed with neurodegenerative diseases (Alzheimer's disease, Parkinson's disease) the composition of gut bacterial biota is different compared to healthy people. Selected types of bacteria, via the gut-brain axis, can affect brain processes.

There are relationships between the composition of the gut microbiota and the occurrence of mental disorders and neurodegenerative diseases in humans. Usually, they are associated with intestinal dysbiosis and leaky gut syndrome.

\section{Keywords}

gut microbiota $•$ gut-brain axis $•$ gut dysbiosis $•$ kinurenine pathway $\bullet$ mental disorders •

neurodegenerative diseases

Received: 27.03.2020, Accepted: 07.07.2021 
Zaburzenia psychiczne oraz choroby neurodegeneracyjne to powszechne zjawisko XXI w. Mimo nieustannego postępu nauk medycznych, wciąż wzrasta liczba osób cierpiących $z$ powodu schorzeń związanych $z$ funkcjonowaniem ośrodkowego układu nerwowego. Patogeneza wielu chorób nie została jeszcze dobrze poznana, dlatego nie można podejmować leczenia przyczynowego, a terapia skupia się na łagodzeniu objawów. W świetle rosnącego zainteresowania mikrobiotą jelitową oraz jej wpływem na ludzkie zdrowie, coraz częściej przeprowadza się badania dotyczące wpływu bioty bakteryjnej jelit na funkcjonowanie mózgu. Jelita bowiem są organem o największej powierzchni, spośród wszystkich znajdujących się w ludzkim ciele, a przy tym są obficie skolonizowane przez symbiotyczne mikroorganizmy. Dwukierunkowa komunikacja między jelitami a mózgiem odbywa się za pośrednictwem osi jelitowo-mózgowej, w wyniku mechanizmów endokrynnych, neuronalnych oraz immunologicznych. Odkrycie tych zależności stało się podstawą badań dotyczących roli szczepów probiotycznych w chorobach układu nerwowego.

W artykule podsumowano aktualny stan wiedzy na temat zależności między składem mikrobioty jelitowej a występowaniem zaburzeń psychicznych i chorób neurodegeneracyjnych u ludzi oraz roli probiotyków w wyżej wymienionych schorzeniach.

\section{Mikrobiota jelitowa}

Jelita to jeden z największych organów ludzkiego organizmu. Na skład mikrobioty wpływa wiele czynników zewnętrznych m.in. sposób porodu, biota bakteryjna matki, dieta, czynniki środowiskowe oraz przyjmowane leki, a zwłaszcza antybiotyki [1]. Skład mikrobioty nie jest identyczny przez całe życie człowieka i zmienia się wraz z wiekiem. Różnice te dotyczą rodzajów oraz liczebności poszczególnych bakterii bytujących $w$ jelicie. Kolonizacja przewodu pokarmowego rozpoczyna się już podczas życia płodowego. W czasie porodu naturalnego noworodek ma kontakt $z$ biotą bakteryjną pochwy oraz przewodu pokarmowego matki, dlatego dominującymi bakteriami u tych dzieci są organizmy z rodzaju Lactobacillus i Prevotella [2]. Inaczej jest u noworodków urodzonych przez cięcie cesarskie, u których bakterie zasiedlające przewód pokarmowy nowo narodzonego człowieka pochodzą ze skóry matki, środowiska szpitalnego i od personelu szpitalnego. Przeważa tu rodzaj Proteobacteria i Firmicutes, a także znaczna liczba organizmów z rodzaju Actinobacteria oraz Clostridium, zwłaszcza Clostridium difficile. W porównaniu do noworodków urodzonych siłami natury mają za to istotnie mniejszą liczbę bakterii z rodzaju Bacteroides i Bifidobacterium [3]. Istotny wpływ na kształtowanie mikrobioty jelitowej ma przede wszystkim rodzaj pokarmu spożywanego przez dziecko. Znacznie bardziej korzystny jest pokarm naturalny, ponieważ jest źródłem prebiotyków - składników aktywnie stymulujących wzrost korzystnych bakterii jelitowych, które mają wpływ na odporność organizmu [2]. Organizmem probiotycznym jest Bifidobacterium longum subsp. infantis, który występuje u noworodków, natomiast nie występuje w składzie bioty bakteryjnej jelit dorosłych [4]. Największe zmiany mikrobioty, związane $z$ wiekiem, zachodzą między 3. dniem a 2. rokiem życia [5]. Badania przeprowadzone wśród duńskich dzieci przez Bergström i wsp. dowiodły, że między 18. a 36. miesiącem życia biota bakteryjna jelit zaczyna się stabilizować i powoli coraz bardziej przypominać mikrobiotę dorosłego człowieka [6]. Od tej chwili zmiany w mikroflorze jelit są mniej gwałtowne. W początkowym odcinku jelita cienkiego (dwunastnica i jelito czcze) występują śladowe ilości bakterii. Znacznie więcej mikroorganizmów znajduje się w końcowym odcinku jelita (jelito kręte). Są to głównie bakterie beztlenowe oraz względnie beztlenowe, a także drożdżaki. Najliczniej zasiedlanym przez drobnoustroje miejscem, nie tylko przewodu pokarmowego, ale i całego ludzkiego organizmu, jest jelito grube. Większość stanowią bakterie bezwzględnie beztlenowe: pałeczki Gram-ujemne i Gram-dodatnie, a także laseczki i ziarenkowce Gramdodatnie reprezentujące gromady Firmicutes i Bacteroidetes. Nieliczny odsetek ogólnej liczby bakterii kałowych stanowią względnie beztlenowe pałeczki Gram-ujemne z rodziny Enterobacteriaceae [7].

\section{Znaczenie mikrobioty jelitowej dla człowieka}

Drobnoustroje pełnią wielorakie funkcje istotne dla utrzymania zdrowia całego organizmu człowieka. Bakterie jelitowe mogą syntetyzować niezbędne dla człowieka witaminy: B1 (tiaminy), B2 (ryboflawiny), B6 (pirydoksyny), B12 (cyjanokobalaminy) oraz $\mathrm{K}$, a także ułatwiają wchłanianie minerałów [8]. Ponadto przeprowadzają proces fermentacji polisacharydów, które nie zostały wcześniej strawione $\mathrm{z}$ udziałem enzymów układu pokarmowego. W wyniku tego procesu powstają krótkołańcuchowe kwasy tłuszczowe (SCFA - short chain fatty acids), m.in. kwas octowy, propionowy i masłowy, które są źródłem energii kolonocytów [9]. Istotnym zadaniem bakterii jelitowych jest zapewnienie bariery na zasadzie stymulacji wytwarzania śluzu przez nabłonek oraz wytwarzanie różnych metabolitów hamujących wzrost bakterii chorobotwórczych. Przykładem mogą być wytwarzane przez bakterie niskocząsteczkowe kwasy tłuszczowe hamujące wzrost pałeczek z rodzaju Salmonella czy też wytwarzane przez pałeczki Escherichia coli bakteriocyny [7, 10]. Prawidłowo funkcjonująca mikrobiota jelitowa wpływa także modulująco na układ immunologiczny gospodarza. Typy komórek układu odpornościowego, które biorą udział w procesie 
immunomodulującym, obejmują tkanki limfoidalne związane z jelitem (GALT - gastrogut associated lymphoid tissue), efektorowe i regulatorowe komórki T, komórki B wytwarzające IgA, komórki limfoidalne z grupy III, rezydentne makrofagi i komórki dendrytyczne w blaszce właściwej błony śluzowej. Reakcje te opierają się na komunikacji bakterii komensalnych z komórkami nabłonka jelit oraz tkankami limfoidalnymi. Odbywa się to przez przekazywanie sygnałów metabolicznym określonym receptorom [11].

\section{Dysbioza jelitowa}

W warunkach fizjologicznego usuwania resztek pokarmowych duża część bakterii jelitowych jest wydalana z kałem. Mikrobiota ma jednak zdolność szybkiego namnażania, dzięki czemu możliwe jest jej ciągłe odnawianie. Niemniej, panująca w końcowym odcinku równowaga może zostać zachwiana na skutek wielu czynników [7]. Taki stan określa się mianem dysbiozy, która może polegać na ekspansji patogenetycznych drobnoustrojów, zredukowaniu różnorodności bakterii lub utracie korzystnych dla gospodarza mikroorganizmów [12]. Dysbioza jest stanem zaburzenia ilościowego i jakościowego bioty bakteryjnej jelit. Jednym z głównych czynników wpływających na skład mikrobioty jest stosowanie antybiotyków. Nawet krótkotrwała antybiotykoterapia często przyczynia się do obniżenia liczby korzystnych dla gospodarza drobnoustrojów jelitowych. Zbyt duże obniżenie liczebności wybranych taksonów może doprowadzić do całkowitej redukcji niektórych gatunków mikroorganizmów, czego skutkiem jest zmniejszona różnorodność. Oznacza to, że o ile u zdrowej osoby występuje bardzo wiele gatunkowo bytujących bakterii symbiotycznych, to u osoby, u której wystąpi dysbioza poantybiotykowa, niektóre z tych gatunków mogą być nieobecne. Jest to stan niekorzystny ze względu na to, że każdy z typów bakterii pełni określone funkcje w ustroju człowieka, a zatem brak któregoś z typów prowadzi do zachwiania homeostazy organizmu ludzkiego. Stosowanie antybiotyków przyczynia się także do zmian w zdolnościach metabolicznych mikrobioty jelit. Bakterie jelitowe tracą wówczas zdolność indukowania mechanizmów obronnych. Organizm ludzki staje się bardziej podatny na ekspansję patogennych szczepów opornych na działanie antybiotyków [13]. Coraz większą uwagę zwraca się na to, że istotny wpływ na zaburzenia w funkcjonowaniu mikrobioty ma również nieprawidłowy sposób odżywiania. Jest to przede wszystkim dieta typu zachodniego, czyli obfitująca w tłuszcze nasycone, cukier, sól, czerwone mięso i jednocześnie uboga w błonnik. Skutkiem takiego sposobu żywienia może być utrata kilku gatunków bakterii, a także późniejsze zmniejszenie liczności i stabilności drobnoustrojów [14]. Wykazano, że dieta typu zachodniego powoduje wyraźne zmniejszenie drobnoustrojów z rodzaju Bifidobacterium, Bacteroides, Prevotella oraz bakterii wytwarzających kwas masłowy przy jednoczesnym wzroście bakterii typu Firmicutes [15]. Różne rodzaje stresu psychicznego także mogą zmieniać składy mikrobioty jelitowej. Do czynników psychologicznych należą m.in.: separacja od matki, niepowodzenia w życiu, gromadzenie w sobie negatywnych emocji, a nawet hałas [16].

\section{Oś jelitowo-mózgowa}

Praca jelit jest kontrolowana przez ośrodki znajdujące się w centralnym układzie nerwowym (CUN). Jednak obecnie coraz większa liczba badań wskazuje na istnienie zależności między składem mikrobioty jelitowej a funkcjonowaniem mózgu. Połączenie umożliwiające dwukierunkową komunikację nosi nazwę osi jelitowo-mózgowej (bądź osi mózg-jelita-mikrobiota). Do jego składowych należą: centralny układ nerwowy, część sympatyczna i parasympatyczna autonomicznego układu nerwowego, układ neuroendokrynny i neuroimmunologiczny, unerwienie jelit oraz biota bakteryjna jelit. Przekaźnictwo sygnałów odbywa się za pośrednictwem mechanizmów neuronalnych, endokrynnych, metabolicznych i immunologicznych $[1,17]$. Ścieżka nerwowa działa poprzez system nerwów jelitowych, główne nerwy autonomicznego układu nerwowego, które kontrolują pracę układu pokarmowego oraz nerw błędny. $W$ ten sposób informacje zmysłowe są przekazywane z narządów wewnętrznych do CUN. Główną rolę odgrywa nerw błędny (X nerw czaszkowy). Aktywacja wyżej wymienionego nerwu jest konieczna do skutecznego oddziaływania mikrobioty jelitowej i probiotyków na mózg [17]. Na drodze endokrynnej mikrobiota jelitowa bierze udział w regulacji osi podwzgórze-przysadka-nadnercza (HPA - hypothalamic-pituitary-adrenal), która odgrywa istotną rolę w reakcji na stres. Działanie HPA opiera się na zasadzie sprzężenia zwrotnego ujemnego, a jego aktywacja pociąga za sobą wiele etapów endokrynologicznych. Wytwarzanie kortykoliberyny ( $\mathrm{CRH}$ - corticotropin-releasing hormone) przez podwzgórze pobudza produkcję hormonu adrenokortykotropowego (ACTH - adrenocorticotropic hormone) w przysadce, a to stymuluje powstawanie kortyzolu - końcowego produktu reakcji, wydzielanego przez korę nadnerczy. W warunkach homeostazy kortyzol jest wydzielany pulsacyjnie przez całą dobę, a fizjologicznie wyższe stężenia we krwi odnotowuje się w pierwszej godzinie po przebudzeniu. Oprócz podstawowego wydzielania, kortyzol jest wydzielany w odpowiedzi na stresory wewnętrzne bądź zewnętrzne $[17,18]$. Wpływ bioty bakteryjnej jelit na funkcjonowanie HPA jako pierwsi wykazali Sudo i wsp. [19]. W badaniach wykorzystali myszy GF (germ free) - dorastające w sterylnych warunkach, całkowicie pozbawione bioty bakteryjnej oraz myszy SPF (specific pathogen free) - pozbawione jedynie 
określonych drobnoustrojów. Zwierzęta zostały poddane czynnikom stresowym, a nadmierne podwyższenie ACTH oraz kortykosteronu zaobserwowano tylko u myszy GF [20]. Inne badanie Sudo i wsp. wykazało, że u myszy GF występują obniżone wartości neurotropowego czynnika pochodzenia mózgowego (BDNF - brain derived neurotropic factor), noradrenaliny, a także serotoniny (5-HT) [21]. Podobne wyniki otrzymał Crumeyrolle-Arias i wsp. [22]. Badanie wykazało, że u szczurów GF brak mikrobioty potęguje odpowiedź neuroendokrynną na stres przy jednoczesnych zmianach szybkości metabolizmu dopaminergicznego w wyższych strukturach mózgu odpowiedzialnych za odpowiedź na stres [22]. Istnieją dowody, że mikrobiota jelitowa odgrywa istotną rolę w aktywności osi HPA, jednak wciąż jeszcze nie wiadomo, jak dokładnie działa mechanizm regulacji. Prawdopodobnie omawiane procesy są pośrednio związane z wytwarzaniem przez układ immunologiczny cytokin proi przeciwzapalnych. Substancje te oddziałują na obszary, takie jak podwzgórze, gdzie interleukiny IL-1 i IL-6, które należą do cytokin prozapalnych, stymulują uwalnianie $\mathrm{CRH}$. Ponadto dowiedziono, że bakterie mogą wytwarzać neurotransmitery i neuromodulatory. Przykładowo, pewne gatunki Lactobacillus i Bifidobacterium syntetyzują kwas $\mathrm{y}$-aminomasłowy (GABA - gamma aminobutyric acid), Escherichia, Bacillus oraz Saccharomyces spp. - noradrenalinę (NA), Candida, Streptococcus, Escherichia i Enterococcus spp. wytwarzają serotoninę, Bacillus - dopaminę, a Lactobacillus acetylocholinę (ACh) [1]. Biota bakteryjna jelit wpływa również na metabolizm tryptofanu za pośrednictwem układu immunologicznego. Drobnoustroje jelitowe mają zdolność obniżania stężenia cytokin prozapalnych, a także modulowania stężenia cytokin przeciwzapalnych. Wybrane cytokiny, a najsilniej IFN- $\gamma$, aktywują enzym szlaku kinureninowego 2,3-dioksygenazę indoloaminy (IDO), którego działanie powoduje przesunięcie tryptofanu ze szlaku syntezy serotoniny do szlaku metabolizmu kinureniny (KYN - kynurenine). Powoduje to obniżenie stężenia 5-HT przy jednoczesnym wzroście stężenia neurotoksycznych CUN metabolitów tryptofanu (m.in. kwasu chinolinowego i 3-hydroksy-kinureniny) [23].

\section{Mikrobiota jelitowa w wybranych zaburzeniach psychicznych}

Do opisywania zaburzeń psychicznych stosuje się głównie dwie metody klasyfikacji: ICD-10 oraz DSM-5. ICD-10 (International Statistical Classification of Diseases and Related Health Problems) to Międzynarodowa Statystyczna Klasyfikacja Chorób i Problemów Zdrowotnych opracowana przez Światową Organizację Zdrowia (WHO - World Health Organization). Została zatwierdzona w maju 1990 r. podczas
43. sesji Światowego Zgromadzenia Zdrowia (WHA - World Health Assembly). Obecnie jest stosowana w ponad 100 krajach na całym świecie. W czerwcu została wydana ICD-11, która oficjalnie będzie obowiązywać w państwach członkowskich od 1 stycznia 2022 roku [24]. DSM-5 (Diagnostic and Statistical Manual of Mental Disorders) jest klasyfikacją zaburzeń psychicznych opracowaną przez Amerykańskie Towarzystwo Psychiatryczne (APA - American Psychiatric Association), została opublikowana w 2013 r. [25].

\section{Depresja}

Depresja jest powszechnym zaburzeniem psychicznym, na całymświecie dotykaponad 300 milionów ludzi wkażdym wieku. Bardzo często uniemożliwia codzienne funkcjonowanie, może prowadzić do samobójstw, które są przyczyną śmierci prawie 800 tys. osób w skali roku [26]. Na podstawie ICD-10 można wyróżnić epizod depresyjny (F32) oraz zaburzenia depresyjne nawracające (F33). Epizod depresyjny, w zależności od liczby i nasilenia objawów, określa się jako łagodny, umiarkowany bądź ciężki. U pacjentów objawia się obniżeniem nastroju, ubytkiem energii, zmniejszeniem aktywności, trudnościami w koncentracji oraz zmęczeniem pojawiającym się nawet po niewielkim wysiłku. Mogą się pojawiać zaburzenia snu oraz brak apetytu. Niemal w każdym przypadku samoocena i pewność siebie są znacznie obniżone, często z towarzyszącym poczuciem winy. Obniżony nastrój nie ulega większym zmianom w kolejnych dniach, nawet pod wpływem bieżących wydarzeń [27]. Zaburzenia depresyjne nawracające są określane jako powtarzające się epizody depresyjne, bez jakichkolwiek niezależnych epizodów wzmożonego nastroju i zwiększonej energii (mania) w przeszłości. W tym przypadku jednak mogą się zdarzać krótkotrwałe stany podwyższenia nastroju i zwiększonej aktywności (hipomania), które mogą być związane ze stosowanymi lekami przeciwdepresyjnymi [27]. Według DSM-5 do zaburzeń depresyjnych można zaliczyć: dezorganizujące zaburzenie regulacji nastroju, większe zaburzenie depresyjne ( $w$ tym epizod większego zaburzenia depresyjnego), uporczywe zaburzenie depresyjne (dystymia), przedmenstruacyjne zaburzenie dysfotyczne, zaburzenie depresyjne wywołane substancją lub lekiem, zaburzenie depresyjne wywołane stanem ogólnomedycznym, inne określone zaburzenia depresyjne oraz nieokreślone zaburzenia depresyjne. Jako główną kategorię w tej grupie zaburzeń wyróżnia się większe zaburzenie depresyjne (MDD - major depressive disorder). Cechuje się odrębnymi epizodami, które trwają minimum 2 tygodnie (jednak w praktyce większość epizodów trwa dłużej) i pociągają za sobą wyraźne zmiany w zakresie afektu, poznania oraz funkcji neurowegetatywnych oddzielonych remisjami. Do rozpoznania MDD konieczne jest spełnienie określonych kryteriów 
diagnostycznych [28]. Występowanie depresji uwarunkowane jest czynnikami temperamentalnymi, środowiskowymi, genetycznymi i fizjologicznymi [28]. W ostatnich latach coraz większą uwagę zwraca się na istnienie zależności między składem mikrobioty jelitowej a występowaniem zaburzeń depresyjnych. Dotychczas zaproponowano kilka ogólnych mechanizmów wykazujących, jak mikrobiota jelitowa, za pośrednictwem osi jelitowo-mózgowej, przyczynia się do powstawania depresji. Proces ten może zostać wywołany np. toczącym się w organizmie stanem zapalnym. W obrębie układu pokarmowego u pacjentów $z$ depresją wykazano zwiększoną aktywność reakcji zapalnych IgA-i IgM-zależnych skierowanych przeciwko lipopolisacharydom Gramujemnych bakterii chorobotwórczych. Inne prawdopodobne mechanizmy dotyczą pośrednictwa osi HPA lub interferencji neurotransmiterów sygnalizacyjnych [29]. Obecnie bardzo popularną hipotezą dotyczącą powiązań między biotą bakteryjną jelit a mózgiem w zaburzeniach psychicznych jest teoria zaburzonej funkcji bariery jelitowej, powszechnie znana jako zespół nieszczelnego jelita (LGS - leaky gut syndrome). Mechanizm ten opiera się na zjawisku uszkodzenia bariery nabłonkowej wywołanej przez dysbiozę jelitową, najczęściej powstającą w wyniku stresu psychicznego lub organicznego. To zwiększa przepuszczalność jelitową, a później translokację bakterii Gram-ujemnych przez błony śluzowe. Przemieszczenie bakterii prowadzi do aktywacji odpowiedzi immunologicznej charakteryzującej się zwiększonym wytwarzaniem cytokin prozapalnych, takich jak IL-6 oraz IFN-y [30]. Maes i wsp. [31] pierwsi wykazali zależność między zespołem nieszczelnego jelita a depresją. $\mathrm{W}$ badaniach dotyczących jelita przesiąkliwego, u pacjentów z MDD w porównaniu do osób zdrowych, zaobserwowano istotnie wyższe stężenia w surowicy przeciwciał IgM i IgA skierowanych przeciwko lipopolisacharydom enterobakterii. Sugeruje to, że translokacja bakteryjna z jelit jest zwiększona u pacjentów z zaburzeniami depresyjnymi, a odpowiedź zapalna może się przyczyniać do zaburzeń nastroju [31]. Istotne różnice zaobserwowano również w składzie mikrobioty jelitowej u osób z zaburzeniami depresyjnymi w porównaniu do osób zdrowych. Naseribafrouei i wsp. [29] przeanalizowali próbki kału pobrane od pacjentów $z$ depresją $(n=37)$ i od grupy kontrolnej $(n=14)$. Najbardziej istotna korelacja między składem bioty bakteryjnej jelit a występowaniem depresji dotyczyła typu Bacteroidetes. Ich ogólna liczba u pacjentów z MDD była niższa w porównaniu z grupą kontrolną, przy jednoczesnym wzroście liczby bakterii z rodzaju Alistipes, które zaliczają się do typu Bacteroidetes. Ponadto zwiększona liczba bakterii z rodzaju Alistipes została również zaobserwowana u osób z zespołem chronicznego zmęczenia oraz zespołem jelita drażliwego. Sugeruje to, że rodzaj Alistipes jest dodatnio skorelowany $z$ występowaniem stanu zapalnego. Można zatem wnioskować, że jeden z patomechanizmów powstawania depresji opiera się na reakcjach zachodzących w szlakach zapalnych. Wykazano też, że u osób z MDD występuje rodzaj Oscillibacter, którego końcowym produktem metabolizmu jest kwas walerianowy. Substancja ta ma bardzo podobną strukturę do GABA, w związku z czym jest zdolna do wiązania się z receptorami GABA. Zwiększone stężenie kwasu walerianowego powoduje, że organizm ludzki reaguje wówczas tak, jakby w krążącej krwi występował nadmiar kwasu $y$-aminomasłowego. W takiej sytuacji może wystąpić ospałość oraz spadek motywacji, które są charakterystyczne dla zaburzeń depresyjnych. Wynika z tego, że obecność w składzie mikrobioty jelitowej bakterii zaangażowanych w wytwarzanie lub metabolizm kwasu walerianowego przyczynia się do występowania objawów typowych dla depresji [29]. Jiang i wsp. [32] również przebadali próbki kału od pacjentów z MDD $(n=46)$ i od zdrowej grupy kontrolnej $(n=30)$. U osób $z$ zaburzeniami depresyjnymi wykryto zwiększoną liczbę bakterii typu Fusobacteria, Proteobacteria i Bacteroidetes. Na poziomie rodziny wzrost liczby dotyczył Rikenellaceae, Porphyromonadaceae, Fusobacteriaceae, Enterobacteriaceae i Acidaminococcaceae. $\mathrm{Na}$ poziomie rodzaju przeważały Roseburia, Oscillibacter, Phascolarctobacterium, Parasutterella, Parabacteroides, Megamonas, Lachnospiracea-incertae sedis, Clostridium XIX, Blautia i Alistipes. Autorzy badania szczególną uwagę zwracają na typ Bacteroidetes i Proteobacteria, których liczba była większa u pacjentów $z$ depresją, podczas gdy bakterii typu Firmicutes było znacznie mniej. Wśród mikroorganizmów typu Bacteroidetes największy wzrost liczby dotyczył rodzajów Alistipes i Parabacteroides. Zauważono również, że ekspresja bakterii z rodziny Lachnospiraceae była obniżona u pacjentów z MDD w porównaniu do zdrowej grupy kontrolnej. Drobnoustroje $z$ rodziny Lachnospiraceae uczestniczą w rozkładzie węglowodanów do krótkołańcuchowych kwasów tłuszczowych. Zmniejszenie liczby takich bakterii przyspiesza ograniczenie wytwarzania SCFA, a to prowadzi do dysfunkcji bariery jelitowej [32]. Wyniki badań przeprowadzonych przez Naseribafrouei i wsp. [29] oraz Jiang i wsp. [32] nie są w pełni zgodne i jednoznaczne. Przypuszcza się, że przyczyną rozbieżności może być wiek uczestników, ponieważ mikrobiota jelitowa człowieka nie jest identyczna w ciągu całego jego życia. Mimo to, na podstawie analizy powyższych badań można stwierdzić, że zmieniony skład bioty bakteryjnej jelit koreluje dodatnio $z$ występowaniem zaburzeń depresyjnych.

\section{Schizofrenia}

Schizofrenia jest uznawana za jedną z najcięższych chorób psychicznych. Szacuje się, że na świecie dotyka ponad 23 miliony osób, z czego większość to mężczyźni [33]. Choroba utrudnia funkcjonowanie nie tylko chorego, ale i jego otoczenia, 
jest nieprzewidywalna i trudna do kontrolowania. Przebieg schizofrenii jest przewlekły, z okresami zaostrzeń i remisji, jednak zaostrzenia zazwyczaj nie są wynikiem czynników zewnętrznych bądź wewnętrznych [34]. Choroba ma typowe objawy, a rozpoznanie jest możliwe do ustalenia na podstawie kryteriów diagnostycznych. W Polsce rozpoznanie dokonuje się w oparciu o ICD-10. Zespół objawów jest często określany jako "4A" i obejmuje:

- Objawy „ambi”:

- ambiwalencja (występowanie sprzecznych uczuć)

- ambisentencja (występowanie sprzecznych sądów)

- ambitendencja (występowanie sprzecznych dążeń)

- Autyzm: wycofanie, odizolowanie się od świata rzeczywistego i skoncentrowanie na życiu wewnętrznym.

- Afekt tępy (sztywność emocjonalna): ekspresja emocjonalna nie odzwierciedla przeżyć wewnętrznych.

- Asocjacje zaburzenia: brak logicznego związku między wypowiadanymi słowami i zdaniami, przy zachowanej świadomości i sprawności intelektualnej chorego.

W latach 80. XX w. zaobserwowano także, że objawy można podzielić na dwie odmienne grupy:

- Objawy pozytywne (wytwórcze): urojenia, omamy, podejrzliwość, wrogość.

- Objawy negatywne (ubytkowe): wycofanie się z kontaktów społecznych, anhedonia, sztywność emocjonalna, trudności w porozumiewaniu spowodowane ubóstwem mowy.

Warto zaznaczyć, że urojenia i omamy nie są typowymi objawami schizofrenii, choć często występują w jej przebiegu. Najczęściej są to omamy słuchowe oraz urojenia ksobne i prześladowcze. Zazwyczaj pojawiają się w fazie zaostrzenia, zatem mogą świadczyć o postępie choroby [34]. Mimo świadomości obrazu klinicznego schizofrenii jej etiologia, patogeneza, a także sposoby zapobiegania nie są dokładnie poznane. Wciąż trwają badania, które pomogłyby odnaleźć przyczynę choroby. Dotychczas określono czynniki, które mogą wpływać na ujawnienie się objawów. Są to głównie:

- Czynniki organiczne - dotyczące zmian strukturalnych w mózgu;

- Czynniki genetyczne - wiążą się z teorią genetycznego dziedziczenia; ryzyko zachorowania na schizofrenię wzrasta, im bliższe jest pokrewieństwo z chorującym;

- Czynniki biochemiczne - dotyczą teorii dopaminowej, która zakłada nadaktywność układu dopaminergicznego;

- Teoria neurorozwojowa - zakłada, że już w trakcie życia płodowego dochodzi do zmian $w$ obrębie centralnego układu nerwowego.

Nie potwierdzono jednak, że wyżej wymienione czynniki są bezpośrednią przyczyną choroby [34]. W ostatnich latach są podejmowane badania mające na celu sprawdzenie istnienia potencjalnych zależności między składem mikrobioty jelitowej a występowaniem schizofrenii. Wyniki dotychczas przeprowadzonych badań sugerują, że zaburzenia psychiczne - w tym schizofrenia - mogą być związane z przewlekłym zapaleniem układu pokarmowego, stresem oksydacyjnym lub dysfunkcjami metabolicznymi [35]. Wykazano również, że u osób chorujących na schizofrenię występuje podwyższony poziom markerów serologicznych charakterystycznych dla translokacji mikrobioty jelitowej. Wskazuje to zatem na współwystępowanie zwiększonej przepuszczalności ściany jelita [36]. Shen i wsp. [37] poddali badaniom próbki kału od 64 pacjentów chorujących na schizofrenię i od 53 zdrowych osób. Wszyscy uczestnicy byli narodowości chińskiej. Próbki od osób zdrowych zawierały przede wszystkim bakterie typu Bacteroidetes, Firmicutes, Proteobacteria i Actinobacteria. W próbkach od osób ze schizofrenią dominowały bakterie typu Bacteroidetes, Firmicutes, Proteobacteria, Actinobacteria i Fusobacteria. Po porównaniu względnej liczby typów bakterii w obu grupach okazało się, że mikrobiota osób ze schizofrenią zawiera większy odsetek bakterii typu Proteobacteria [37]. W próbkach grupy kontrolnej przeważał rodzaj Bacteroides, Prevotella, Faecalibacterium, Sutterella, Ruminococcus i Parabacteroides. W próbie badanej dominującym rodzajem był również Bacteroides, a po nim Prevotella, Faecalibacterium i Succinivibrio. Po porównaniu wyników z obu grup, okazało się, że bakterie z rodzaju Succinivibrio, Megasphaera, Collinsella, Clostridium, Klebsiella i Methanobrevibacter liczniej występowały wśród grupy badanej w porównaniu do grupy kontrolnej. Drobnoustroje z rodzaju Blautia, Coprococcus i Roseburia w większej liczbie występowały wśród grupy kontrolnej w porównaniu do grupy badanej. Bakterie z rodzaju Blautia, Coprococcus i Roseburia uczestniczą w rozkładzie węglowodanów do krótkołańcuchowych kwasów tłuszczowych. Zmniejszona liczba tych drobnoustrojów jest związana z redukcją SCFA. Wyniki badania sugerują zatem, że mniejsza liczba wyżej wymienionych mikroorganizmów może się przyczyniać do dysfunkcji ściany jelit. W próbkach od osób chorych na schizofrenię wykryto również większą liczbę drobnoustrojów z rodzaju Collinsela, które prawdopodobnie wytwarzają interleukinę 17a [37]. Nguyen i wsp. [38] jako pierwsi przeprowadzili badanie mikrobioty jelitowej wśród pacjentów chorujących na schizofrenię mieszkających na terenie Stanów Zjednoczonych. Poddali pomiarom 50 próbek kału: 25 od osób ze schizofrenią i 25 od osób zdrowych. Wykazano, że liczba drobnoustrojów typu Proteobacteria była mniejsza w próbkach od osób ze schizofrenią niż u osób zdrowych. W próbkach od osób chorujących na schizofrenię liczniej występowały jedynie bakterie z rodzaju Anaerococcus, podczas gdy mikroorganizmyzrodzaju Haemophilus, Sutterella i Clostridium występowały mniej licznie w porównaniu do próbek osób zdrowych. Wyniki wyżej wymienionych badań są niejednoznaczne. W badaniu Shen i wsp. [38] liczba bakterii typu Proteobacteria u osób ze schizofrenią była wyższa niż u osób zdrowych, natomiast w badaniu Nguyen i wsp. [37] 
u pacjentów ze schizofrenią występowała mniejsza liczba Proteobacteria niż u osób z grupy kontrolnej. Poza tym wyniki są zgodne, mimo różnic narodowościowych grup badanych. Można zatem wnioskować, że patogeneza oraz przebieg schizofrenii korelują dodatnio ze zmienionym składem bioty bakteryjnej jelit. Zagadnienie to nie jest jednak wystarczająco dobrze poznane i wymaga potwierdzenia w dalszych badaniach.

\section{Jadłowstręt psychiczny}

Zaburzenia odżywiania tworzą grupę zaburzeń psychicznych charakteryzujących się specyficznymi objawami psychopatologicznymi, które prowadzą do zaburzeń fizjologicznych oraz powikłań somatycznych. Jednym z najbardziej powszechnych zaburzeń odżywiania jest jadłowstręt psychiczny (AN - anorexia nervosa), potocznie nazywany anoreksją [34]. Jadłowstręt psychiczny ma przebieg przewlekły. Charakteryzuje się utratą masy ciała celowo wywołaną i/lub podtrzymywaną przez osobę chorą. Według ICD-10 typowe objawy to:

- Masa ciała utrzymująca się na poziomie co najmniej $15 \%$ oczekiwanej albo wskaźnik masy ciała Queteleta (Body Mass Index, BMI) na poziomie $17,5 \mathrm{~kg} / \mathrm{m}^{2}$ lub mniej;

- Utrata masy ciała spowodowana przez celowe unikanie pokarmów, często za pomocą wymienionych czynności: prowokowanie wymiotów, stosowanie środków przeczyszczających i/lub moczopędnych, wyczerpujące ćwiczenia fizyczne, stosowanie leków tłumiących łaknienie;

- Zaburzone postrzeganie własnego ciała, przyjmujące postać zespołu psychopatologicznego - obawa przed otyłością pojawia się $\mathrm{w}$ formie natrętnej myśli nadwartościowej;

- Zaburzenia hormonalne prowadzące do zatrzymania miesiączki u kobiet oraz spadku popędu seksualnego u mężczyzn. Wyjątek: menstruacja u kobiet przyjmujących hormonalne leki substytucyjne (najczęściej antykoncepcja hormonalna).

Występowanie wszystkich wyżej wymienionych objawów jest podstawą rozpoznania [34]. Jadłowstręt psychiczny można podzielić na dwa typy: restrykcyjny i bulimicznooczyszczający. Pierwszy typ jest najbardziej powszechny i polega na surowych restrykcjach żywieniowych. W typie bulimiczno-oczyszczającym pacjenci również ograniczają ilość przyjmowanego pokarmu, jednak występują u nich często napady kompulsywnego objadania się. Każde spożycie jednorazowo dużej ilości żywności wywołuje poczucie winy u chorego, a to prowadzi do prowokowania wymiotów lub stosowania środków przeczyszczających [39]. W diagnozie jadłowstrętu psychicznego bardzo istotne jest różnicowanie symptomów, ponieważ zaburzenie to często współwystępuje zinnymi chorobami. Często towarzyszy mu depresja, natręctwa czy zaburzenia osobowości. Spośród somatycznych objawów należy również wykluczyć przewlekłe choroby wyniszczające, guzy mózgu, zespół złego wchłaniania czy nieswoiste zapalenia jelit, tj. choroba Crohna, wrzodziejące zapalenie jelita grubego [34]. Etiologia jadłowstrętu psychicznego jest skomplikowana i wieloczynnikowa. Do czynników biologicznych możnazaliczyćm.in. predyspozycje genetyczne, podwyższone stężenie greliny, obniżone stężenie leptyny, a także mniejszą aktywność obszaru mózgu zwanego wyspą (insula). Wśród czynników pozabiologicznych wyróżnia się czynniki rodzinne, społeczno-kulturowe i czynniki poznawcze [34]. Obecnie obiektem zainteresowania wielu naukowców jest przypuszczalne istnienie związku między składem bioty bakteryjnej jelit a występowaniem jadłowstrętu psychicznego. Morita i wsp. [39] przeprowadzili badanie mające na celu porównanie składu bioty bakteryjnej jelit osób chorujących na anoreksję i osób zdrowych. Analizie poddano próbki kału od 25 kobiet chorujących na jadłowstręt psychiczny, w tym 14 typu restrykcyjnego i 11 typu bulimiczno-oczyszczającego oraz 21 zdrowych kobiet. Badanie wykazało, że ogólna liczba bakterii jelitowych u kobiet $z$ jadłowstrętem psychicznym była obniżona w porównaniu do kobiet zdrowych. Zmniejszenie liczby dotyczyło zwłaszcza bakterii z gatunku Clostridium coccoides, Clostridium leptum, Bacteroides fragilis, Lactobacillus plantarum oraz z rodzaju Streptococcus. W kale $45 \%$ pacjentek $z$ anoreksją typu bulimiczno-oczyszczającego stwierdzono obecność Clostridium difficile, podczas gdy nie wykryto tego drobnoustroju w próbkach od pacjentek $z$ anoreksją typu restrykcyjnego, a także w próbkach od kobiet zdrowych. Ponadto $w$ próbkach $z$ grupy badanej wykryto znacznie mniejsze stężenia kwasu octowego i propionowego niż w grupie kontrolnej. Świadczy to o zmniejszonej liczbie bądź obniżonej aktywności bakterii fermentujących węglowodany złożone do krótkołańcuchowych kwasów tłuszczowych. Niskie stężenia SCFA osłabiają barierę jelitową oraz przyczyniają się do powstania dysbiozy [39]. Różnice dotyczące składu bioty bakteryjnej jelit zostały także udowodnione $w$ badaniu przeprowadzonym przez Kleiman i wsp. [40]. Przeanalizowano próbki kału od 12 zdrowych kobiet, a także od 16 pacjentek z jadłowstrętem psychicznym. Próbki od pacjentek z AN zostały przeanalizowane dwukrotnie - przed rozpoczęciem leczenia (grupa badana pierwsza) oraz po zakończeniu kuracji związanej z przyrostem masy ciała (grupa badana druga). Wyniki analizy kału od pacjentek z jadłowstrętem psychicznym przed rozpoczęciem leczenia znacznie się różniły od wyników uzyskanych z analizy próbek zdrowych kobiet oraz pacjentek po przebytej kuracji. W próbkach kału pacjentek $z$ grupy badanej pierwszej wykryto zwiększoną liczbę drobnoustrojów z klasy Bacilli $\mathrm{i}$ bakterii $\mathrm{z}$ rodziny Coriobacteriales oraz zmniejszoną liczbę klasy Clostridia, w tym rzędu Clostridiales, 
rodzaju Anaerostipes, a także rodzaju Faecalibacterium w porównaniu do próbek kału kobiet zdrowych. Podczas zestawienia próbek od pacjentek $z$ grupy badanej drugiej $z$ próbkami od kobiet $z$ grupy kontrolnej, jedyną pozostałą różnicą z wyżej wymienionych, była obecność bakterii z rodziny Coriobacteriales $w$ kale pacjentek, które zostały poddane leczeniu. Wyniki badania wskazują, że wraz z przyrostem masy ciała zwiększyła się różnorodność taksonomiczna oraz ogólna liczebność bakterii jelitowych u kobiet chorujących na jadłowstręt psychiczny [40]. Powyższe badania wskazują na istotny związek występowania jadłowstrętu psychicznego ze składem mikrobioty jelitowej. Trudno jednak stwierdzić, czy dysbioza jelitowa jest przyczyną, czy raczej skutkiem anoreksji. Ze względu na specyfikę schorzenia, zmieniony skład bioty bakteryjnej jelit może być wynikiem restrykcji żywieniowych stosowanych przez chorujących. Mimo to przypuszcza się, że zmiany w składzie mikrobioty mogą się przyczyniać do wystąpienia objawów depresyjnych, które często towarzyszą AN.

\section{Autyzm}

Autyzm dziecięcy, według ICD-10, zaliczany jest do grupy całościowych zaburzeń rozwojowych i stanowi ich najcięższą postać. Charakteryzuje się nieprawidłowym lub zaburzonym rozwojem przed ukończeniem trzeciego roku życia, a także wadliwym funkcjonowaniem w trzech obszarach psychopatologii (interakcje społeczne, komunikacja, zachowanie) [27]. W klasyfikacji DSM-5 nie wyodrębnia się poszczególnych jednostek chorobowych. Wszystkie zaburzenia, w których występują objawy autystyczne (autyzm dziecięcy, zespół Aspergera, autyzm atypowy, dziecięce zaburzenia dezintegracyjne, całościowe zaburzenia rozwoju nieokreślone), zalicza się do „grupy zaburzeń ze spektrum autyzmu" (ASD - autism spectrum disorder) [34]. Najbardziej charakterystyczne objawy, występujące już w okresie niemowlęcym i wczesnodziecięcym to: obojętność lub awersja na kontakt fizyczny, zaburzenia kontaktu wzrokowego, brak reakcji na głos rodziców, brak zabaw związanych z naśladowaniem, trudności ze snem. Zazwyczaj u dzieci autystycznych występuje nieprawidłowy rozwój mowy, a część z nich nigdy nie zaczyna mówić. Zasadnicze symptomy w tym okresie dotyczą braku zdolności do dzielenia uwagi (np. dziecko nie podąża swoim wzrokiem za wzrokiem osoby dorosłej) oraz wskazywania protodeklaratywnego (dziecko nie wskazuje palcem przedmiotu lub sytuacji, które przykuły jego uwagę). W wieku przedszkolnym lub szkolnym można zaobserwować brak zdolności podtrzymania rozmowy, brak chęci uczestnictwa w zabawach grupowych, brak zrozumienia zasad współżycia, deficyty w myśleniu abstrakcyjnym czy też sprzeciwianie się zmianom i tendencja do zachowywania stałości [34]. Etiologia zaburzeń ze spektrum autyzmu pozostaje wciąż niejasna. Przypuszcza się, że przyczyny są uwarunkowane wieloczynnikowo i mają związek z nieprawidłowym rozwojem lub wczesnym uszkodzeniem struktur centralnego układu nerwowego [34]. Obecnie są prowadzone badania mające na celu przeanalizowanie powiązań między składem mikrobioty jelitowej a występowaniem ASD. Lee i wsp. [41] zaobserwowali, że istnieją różnice w składzie mikrobioty dzieci autystycznych i dzieci zdrowych. W badaniu tym poddano analizie próbki moczu, w których znajdowały się pęcherzyki zewnątrzbłonowe bakterii jelitowych. Próbki pobrano od 20 osób z zaburzeniami ze spektrum autyzmu (grupa badana) i od 28 zdrowych osób (grupa kontrolna). Wśród osób z grupy badanej zaobserwowano istotnie mniejszą liczebność bakterii typu Proteobacteria i Cyanobacteria, a także zwiększoną liczbę drobnoustrojów typu Firmicutes oraz Verrucomicrobia w porównaniu do osób z grupy kontrolnej. U osób z ASD liczba bakterii z rodzaju Pseudomonas, Sphingomonas, Agrobacterium, Roseateles i Achromobacter była mniejsza niż u osób zdrowych. Drobnoustroje z rodzaju Streptococcus, Halomonas, Akkermansia i Rhodococcus miały zwiększony udział w ogólnej liczbie bakterii grupy badanej w porównaniu do grupy kontrolnej [41]. Różnice w składzie mikrobioty jelitowej wykazali także Coretti i wsp. [24]. W badaniu przeanalizowano próbki kału od 11 dzieci z ASD (grupa badana) i od 12 dzieci zdrowych (grupa kontrolna). Wyniki badania wykazały, że zarówno w grupie badanej jak i kontrolnej największy odsetek drobnoustrojów tworzących mikrobiotę jelitową stanowiły bakterie typu Firmicutes. Ponadto wyniki wskazują na obniżoną liczbę drobnoustrojów typu Actinobacteria oraz podwyższoną liczbę Bacteroidetes i Proteobacteria w próbkach od dzieci z ASD w porównaniu z próbkami od dzieci zdrowych. $\mathrm{Na}$ poziomie rodziny liczba bakterii Actinomycetaceae, Coriobacteriaceae, Bifidobacteriaceae, Gemellaceae i Streptococcaceae była niższa u pacjentów z grupy badanej niż u osób zdrowych. Autorzy badania szczególną uwagę zwracają na zwiększoną liczbę Bacteroidetes, która może wpływać na stężenie krótkołańcuchowych kwasów tłuszczowych. Analiza zawartości poszczególnych SCFA w badanych próbkach kału wykazała, że w obu grupach stężenie SCFA mieści się w dopuszczalnych granicach, jednak u pacjentów z ASD występuje wyższe stężenie kwasu propionowego (propanowego) i masłowego (butanowego) niż u osób zdrowych. Wyniki sugerują zatem różnice w zdolnościach przeprowadzania procesów fermentacji przez mikrobiotę jelitową obu badanych grup. Wydaje się, że znaczenie może tu mieć wzrost liczby bakterii z gatunku Faecalibacterium prausnitzii u dzieci z ASD. Drobnoustroje F. prausnitzii są znane jako najbardziej butyrogenne bakterie spośród bytujących w ludzkim jelicie, co oznacza, że bardzo intensywnie metabolizują polisacharydy do kwasu 
masłowego. Ponadto kwas butanowy może być również syntetyzowany w wyniku degradacji mucyny, która jest glikoproteinowym składnikiem chroniącym błonę śluzową jelita. Wyniki badania wykazały, że u dzieci zASD występowało znacznie wyższe stężenie beta-heksoaminidazy - enzymu odpowiadającego za degradację mucyny. Zaobserwowano, że wysokie stężenie beta-heksoaminidazy u pacjentów z ASD korelowało ze zwiększoną liczbą mikroorganizmów z gatunku Ruminococcus torques, które są zdolne do degradacji mucyny. Deficyt substancji powlekającej błonę śluzową jelita może się przyczynić do wzrostu przepuszczalności nabłonka jelitowego, a tym samym wpłynąć na rozwój zespołu nieszczelnego jelita [42]. Zwiększenie przepuszczalności nabłonka jelitowego powoduje przenikanie do krwiobiegu różnych substancji. W autyzmie opisano przypadki, w których wzrost stężenia kwasu propanowego w surowicy krwi był skorelowany z ujawnieniem się zachowań autystycznych. Badania te zostały jednak przeprowadzone na modelach zwierzęcych i wymagają potwierdzenia u ludzi [43].

Badania przeprowadzone przez Lee i wsp. [41] oraz Coretti i wsp. [24] wskazują na istnienie różnic w składzie mikrobioty jelitowej osób zdrowych i osób z ASD. Jednak ze względu na to, że etiologia autyzmu nie została jak dotąd dobrze poznana i nie ustalono, czy za patogenezę tych zaburzeń odpowiadają konkretne substancje, trudno określić, czy dysbioza ma bezpośredni wpływ na rozwój zaburzeń ze spektrum autyzmu.

Mikrobiota jelitowa w wybranych chorobach neurodegeneracyjnych

Choroby neurodegeneracyjne to grupa schorzeń, których istotą jest postępujący zanik komórek nerwowych. Tego typu zaburzenia objawiają się przede wszystkim u osób po 50. roku życia, a ich najczęstsza postać to choroba Alzheimera (AD - Alzheimer disease) oraz Parkinsona (PD - Parkinson disease). Ze względu na zjawisko starzenia się społeczeństw, wzrasta odsetek ludzi cierpiących na zespoły otępienne. W związku z tym, istotne znaczenie ma właściwa diagnostyka i terapia schorzeń wieku starczego [44].

\section{Choroba Alzheimera}

Choroba Alzheimera stanowi ponad 50\% przypadków otępienia; początek choroby objawia się głównie zaburzeniami pamięci, a z czasem także innych funkcji poznawczych. W wyniku postępu $A D$, osoba chora miewa trudności w nazywaniu przedmiotów, wykonywaniu prostych codziennych czynności, rozpoznawaniu znanych przedmiotów oraz twarzy. Przyczyną tych nieprawidłowości jest zanik neuronów, głównie układu limbicznego - struktur korowych i podkorowych mózgu odpowiedzialnych za pamięć oraz procesy emocjonalne. Charakteryzuje się występowaniem w mózgu m.in. blaszek amyloidowych (tzw. blaszek starczych) oraz zwyrodnień neurofibrylarnych (NFT - neurofibrillary tangles) [45]. W warunkach fizjologicznych prekursorowe białko amyloidu $\beta$ (APP - amyloid precursor protein) jest składnikiem błony komórkowej neuronu, a także uczestniczy w transporcie aksonalnym. Może jednak dojść do zaburzeń w przemianach APP, co prowadzi do powstania nierozpuszczalnych form $\beta$-amyloidu, które odkładają się wewnątrz- oraz zewnątrzkomórkowo w postaci blaszek amyloidowych. Nierozpuszczalne formy $\beta$-amyloidu powodują hiperfosforylację białka tau, charakterystycznego dla komórek układu nerwowego. W wyniku tego procesu hiperfosforylowane białko tau odkłada się w postaci zwyrodnień neurofibrylarnych, które prowadzą do obumierania neuronów. $\mathrm{Na}$ podstawie liczby oraz rozmieszczenia blaszek starczych i neuronów z cechami zwyrodnienia neurofibrylarnego stawia się rozpoznanie choroby Alzheimera [44]. W ostatnim czasie obiektem badań w przebiegu AD stała się biota bakteryjna jelit. Vogt i wsp. [46] przeprowadzili badanie mające na celu przeanalizowanie składu mikrobioty jelitowej osób ze zdiagnozowaną chorobą Alzheimera. Od 25 pacjentów chorujących na AD (próba badana) i od 25 osób zdrowych (grupa kontrolna) zebrano próbki kału, które przebadano. Wyniki wykazały, że w próbkach grupy badanej liczba bakterii typu Firmicutes oraz Actinobacteria była niższa, a typu Bacteroidetes wyższa niż w próbkach grupy kontrolnej [46]. Analizy próbek pacjentów z AD wykazały, że liczba bakterii z rodziny Ruminococcaceae, Turicibacteraceae, Peptostreptococcaceae, Clostridiaceae oraz Mogibacteriaceae była niższa, a z rodziny Gemellaceae wyższa niż w próbkach od osób zdrowych. Ponadto jelita osób chorujących na AD były zasiedlone przez większą liczbę bakterii z rodzaju Blautia, Phascolarctobacterium oraz Gemella, natomiast mniejszą liczbę bakterii z rodzaju Dialister, Clostridium, Turicibacter, SMB53 (rodzina Clostridiaceae) oraz cc115 (rodzina Erysipelotrichaceae) niż jelita osób zdrowych [46]. Vogt i wsp. podkreślają, że obniżona liczba bakterii typu Firmicutes może wpływać hamująco na metabolizm glukozy, za pośrednictwem osi jelitowo-mózgowej. Przypuszcza się, że obniżony metabolizm mózgowy glukozy jest związany ze zwiększonym odkładaniem się blaszek amyloidowych [47]. W przebiegu choroby Alzheimera stwierdzono również znacznie podwyższony poziom Gram-ujemnych bakterii typu Bacteroidetes. Składnikiem błony komórkowej tych bakterii są lipopolisacharydy - związki zdolne do wywoływania reakcji zapalnej $w$ organizmie ludzkim. Wystąpienie stanu zapalnego powoduje uwolnienie cytokin prozapalnych w chwili przeniknięcia endotoksyn bakteryjnych do krążenia ogólnego. U ludzi przepuszczalność jelit wzrasta z wiekiem. 
Można zatem przypuszczać, że osoby starsze są bardziej narażone na migrację endotoksyn ze światła jelita do krążenia ogólnego [46]. Zhan i wsp. [48] przebadali post mortem tkanki mózgowe pacjentów ze zdiagnozowaną za życia chorobą Alzheimera. Uzyskane wyniki wykazały, że obecność LPS koreluje dodatnio $z$ występowaniem blaszek starczych w mózgu osób z AD [48]. Sugeruje to, że wzrost liczby bakterii Gram-ujemnych w obrębie układu pokarmowego oraz wzrost stężenia ich endotoksyn w krążeniu ogólnym, może zwiększać ryzyko wystąpienia choroby Alzheimera.

\section{Choroba Parkinsona}

Choroba Parkinsona to oprócz choroby Alzheimera najczęstsza choroba neurodegeneracyjna; dotyczy głównie osób po 50. roku życia [44]. Jednym z jej pierwszych symptomów jest drżenie spoczynkowe rąk. Z czasem pojawia się wzmożenie napięcia mięśniowego w postaci sztywności mięśniowej, chód drobnymi krokami, zmieniona mowa oraz zmiana charakteru pisma. Typowym objawem PD jest postawa zgięciowa (zgięcie w stawie krzyżowo-biodrowym). Ponadto chorzy odczuwają bóle mięśni, trudności $w$ rozpoczęciu ruchu, a także kłopoty z utrzymaniem przez dłuższy czas jednej pozycji. Dla tego schorzenia charakterystyczne są także objawy wegetatywne, takie jak zaparcia czy trudności w oddawaniu moczu [45]. Patogeneza choroby Parkinsona jest związana ze zmianami neurozwyrodnieniowymi istoty czarnej śródmózgowia, odpowiedzialnej za wytwarzanie neurotransmitera - dopaminy. Następstwem zaniku neuronów istoty czarnej jest zmniejszenie ilości dopaminy w prążkowiu. Zaburza to równowagę między układem dopaminergicznym i układem cholinergicznym. Aktualny stan wiedzy na temat patogenezy PD uwzględnia zarówno czynniki genetyczne, jak i środowiskowe. Genetycznie uwarunkowana choroba Parkinsona jest związana $z$ mutacją $w$ genie białka zwanym a-synukleiną. Mutacja powoduje nieprawidłową budowę tego białka, które odkłada się w postaci wtrętów (ciała Lewy'ego) w komórkach nerwowych. Skutkiem tego zjawiska jest śmierć neuronów w procesie apoptozy. Do czynników środowiskowych zalicza się m.in. stres oksydacyjny, który jest związany z działaniem wolnych rodników [44]. Przypuszcza się także, że $w$ przebiegu choroby istotną rolę odgrywa skład mikrobioty jelitowej pacjentów. Unger i wsp. [49] porównali próbki kału osób zdrowych (grupa kontrolna) i osób chorujących na PD (grupa badana). W badaniu wykazano, że w składzie mikrobioty jelitowej pacjentów z PD występuje zmniejszona liczba drobnoustrojów typu Bacteroidetes, z czego największa redukcja liczby bakterii dotyczyła rodziny Prevotellaceae. Ponadto w próbkach od osób z grupy badanej zaobserwowano mniejszą liczbę bakterii z gatunku Faecalibacterium prausnitzii, a także z rodzin
Lactobacillaceae oraz Enterococcaceae niż w próbkach od osób z grupy kontrolnej. Skład bioty bakteryjnej jelit pacjentów z chorobą Parkinsona charakteryzował się zwiększoną liczbą drobnoustrojów z rodzaju Bifidobacterium, rodziny Enterobacteriaceae oraz z gatunku Akkermansia muciniphila. [49]. Wyniki badania przeprowadzonego przez Unger i wsp. [49] częściowo pokrywają się z wynikami uzyskanymi w badaniu Hasegawa i wsp. [50]. W tym badaniu również porównano próbki kału osób zdrowych i osób chorujących na PD. Wykazano, że w składzie mikrobioty jelitowej osób z PD występuje istotnie mniejsza liczba bakterii z rodzaju Prevotella, a także z gatunku Clostridium coccoides oraz Bacteroides fragilis przy jednoczesnym wzroście liczby bakterii z rodzaju Lactobacillus w porównaniu do osób zdrowych. Podobieństwa w uzyskanych wynikach dwóch wyżej przytoczonych badań dotyczą zatem drobnoustrojów z rodzaju Prevotella oraz Bacteroides [50]. Wyniki badań przeprowadzonych przez Minato i wsp. [51] sugerują, że skład bioty bakteryjnej jelit może determinować przebieg choroby Parkinsona. Dwuletnie obserwacje wykazały, że obniżenie liczby bakterii z rodzaju Bifidobacterium, a także z gatunku Bacteroides fragilis oraz Clostridium leptum towarzyszyło nasilenie objawów PD [51]. Wyniki wyżej wymienionych badań dowodzą istnienia wyraźnych różnic pomiędzy składem bioty bakteryjnej jelit osób zdrowych i osób z chorobą Parkinsona. Przypuszczalnie kompozycja mikrobioty jelitowej odgrywa istotną rolę w przebiegu PD, jednak mechanizm tych zależności nie został jeszcze dokładnie poznany i wymaga dalszych badań. Zasadne wydaje się jednak wykorzystanie analizy składu mikrobioty jelitowej jako kryterium pomocnicze w rozpoznaniu choroby Parkinsona.

\section{Podsumowanie}

Obecny stan wiedzy wskazuje na istnienie korelacji między składem mikrobioty jelitowej a występowaniem zaburzeń psychicznych i chorób neurodegeneracyjnych. W zależności od liczby drobnoustrojów z poszczególnych kategorii taksonomicznych, a także proporcji między nimi, do mózgu są wysyłane określone sygnały na drodze endokrynnej, immunologicznej i neuronalnej. Komunikacja odbywa się za pośrednictwem osi jelitowo-mózgowej. Wyniki analizowanego piśmiennictwa wykazują, że skład bioty bakteryjnej w wybranych zaburzeniach psychicznych i chorobach neurodegeneracyjnych jest odmienny od składu mikrobioty kolonizującej jelita osób bez powyższych schorzeń. Najpopularniejszą koncepcją tłumaczącą zależności między składem mikrobioty jelitowej a występowaniem chorób związanych z centralnym układem nerwowym, jest teoria nieszczelnego jelita. LGS jest przeważnie wywołany dysbiozą jelitową, czyli stanem zaburzenia ilościowego i jakościowego 
bioty bakteryjnej jelit. Skutkiem zmniejszenia integralności bariery jelitowej jest przemieszczenie się patogenów oraz wytwarzanych przez nich substancji szkodliwych do krążenia ogólnego. Następstwem tego zjawiska jest powstanie stanu zapalnego w organizmie ludzkim. W przypadku osób chorujących na depresję, szczególną uwagę zwrócono na zwiększoną liczbę bakterii z gatunku Alistipes. Podwyższona liczba tych mikroorganizmów została także wykryta u osób chorujących na inne choroby, którym towarzyszy stan zapalny. Sugeruje to, że gatunek Alistipes ma związek z występowaniem w organizmie procesu zapalnego, który przypuszczalnie odgrywa rolę w patogenezie zaburzeń depresyjnych. Sporna pozostaje liczba bakterii typu Bacteroidetes kolonizujących jelita osób z MDD. Wyniki niektórych badań wykazały, że liczba tych drobnoustrojów jest mniejsza niż u osób zdrowych, natomiast wyniki innych badań wskazują na zwiększoną liczbę mikroorganizmów typu Bacteroidetes u osób z depresją w porównaniu do osób zdrowych. Niewykluczone, że różnice te wynikają z tego, iż przytoczone badania zostały przeprowadzone na różnych kontynentach. W związku z tym, różnice w składzie mikrobioty jelitowej mogą mieć związek z klimatem panującym w danym regionie czy pokarmem spożywanym w konkretnym kraju. Z tego względu zagadnienie to wymaga dalszych badań w celu doprecyzowania, czy drobnoustroje typu Bacteroidetes pełnią określoną rolę w patomechanizmie zaburzeń depresyjnych. Odmienności w składzie mikrobioty jelitowej zostały również wykryte u osób ze zdiagnozowaną schizofrenią. Jelita tych osób były silnie skolonizowane bakteriami z rodzaju Succinvibrio. U zdrowych osób z próby kontrolnej rodzaj ten występował w znikomych ilościach. Oprócz tego, w składzie bioty bakteryjnej jelit osób chorujących na schizofrenię występowała mniejsza liczba bakterii z rodzaju Blautia, Coprococcus i Roseburia. Wymienione drobnoustroje są odpowiedzialne za rozkład węglowodanów złożonych do krótkołańcuchowych kwasów tłuszczowych. Obniżona synteza SCFA może powodować dysfunkcję ściany jelita, czego następstwem jest zmniejszenie integralności bariery jelitowej. Wówczas do krążenia ogólnego przedostają się substancje o niekorzystnym dla gospodarza działaniu. Rola tego zjawiska jest podkreślana, gdyż przypuszcza się, że komponenta zapalna także może mieć znaczenie w patomechanizmie schizofrenii. $U$ osób chorujących na jadłowstręt psychiczny także zaobserwowano zmieniony skład bioty bakteryjnej jelit w porównaniu do osób bez zaburzeń odżywiania. Oprócz różnic w liczbie poszczególnych taksonów, wyniki wykazały zmniejszoną liczbę drobnoustrojów ogółem. Jednak po uzyskaniu przez pacjentki masy ciała mieszczącej się w zalecanej normie, skład ich mikrobioty jelitowej prawie niczym się nie różnił od składu mikrobioty jelitowej osób zdrowych. Jedyną różnicą była obecność bakterii z rodziny Coriobacteriales u osób chorujących na AN, które zwiększyły swoją masę ciała.
Przypuszczalnie, ze względu na specyfikę omawianego schorzenia, zmieniony skład bioty bakteryjnej jelit wynika z restrykcji żywieniowych. W oparciu o analizowane piśmiennictwo nie można zatem stwierdzić, że zachowania typowe dla osób chorujących na anoreksję są bezpośrednim wynikiem zmian w mikrobiocie jelitowej. Autorzy badań sugerują jednak, że zmieniona $\mathrm{z}$ powodu choroby biota bakteryjna, może nasilać objawy depresyjne, które często towarzyszą AN. Wyniki badań przeprowadzonych wśród dzieci z zaburzeniami ze spektrum autyzmu wykazały, że u pacjentów z ASD występowało zwiększone stężenie $\beta$-heksoaminidazy (enzymu odpowiadającego za degradację mucyny). Ponadto wzrost stężenia tej substancji korelował dodatnio ze wzrostem liczby bakterii z gatunku Rumonococcus torques, które również wykazują zdolność degradacji mucyny. Sugeruje to, że w przebiegu autyzmu istotne znaczenie ma wzrost przepuszczalności bariery jelitowej. Jednak biorąc pod uwagę to, że etiologia ASD nie została jak dotąd dokładnie poznana, nie można jednoznacznie określić, w jaki sposób drobnoustroje wchodzące w skład mikrobioty jelitowej lub ich produkty mają wpływ na występowanie tych zaburzeń. W przebiegu chorób neurodegeneracyjnych również zaobserwowano zmieniony skład bioty bakteryjnej jelit. U osób ze zdiagnozowaną chorobą Alzheimera stwierdzono zmniejszoną liczbę bakterii typu Firmicutes, która przypuszczalnie działa hamująco na mózgowy metabolizm glukozy, za pośrednictwem osi jelitowo-mózgowej. Zjawisko to może nasilać odkładanie blaszek amyloidowych w mózgu. Ponadto $u$ osób $z$ AD występowała zwiększona liczba drobnoustrojów typu Bacteroidetes, które są bakteriami Gram-ujemnymi, a integralną część ich błony komórkowej stanowią lipopolisacharydy. Autorzy sugerują, że zwielokrotnienie liczby występujących mikroorganizmów typu Bacteroidetes w jelitach wpływa na obecność LPS w mózgu, a to jest skorelowane dodatnio z obecnością blaszek starczych w mózgu. U pacjentów z chorobą Parkinsona stwierdzono obniżoną liczbę bakterii typu Bacteroidetes, a zwłaszcza rodziny Prevotellaceae, która zalicza się do wyżej wymienionego typu. Jednak przypuszczalnie, największe znaczenie w rozwoju PD mają drobnoustroje z rodzaju Bifidobacterium. Ich liczba u osób z chorobą Parkinsona była niższa niż u osób zdrowych. Podczas obserwacji osób chorych stwierdzono, że objawy PD rosną wprost proporcjonalnie do zmniejszającej się $w$ jelitach liczby mikroorganizmów z rodzaju Bifidobacterium. Wyniki potwierdzające zmieniony skład mikrobioty jelitowej u osób ze schorzeniami układu nerwowego skłoniły naukowców do podjęcia badań dotyczących możliwości modulowania przebiegu tych chorób za pomocą osi jelitowo-mózgowej. W tym celu użyto bakterii probiotycznych - mikroorganizmów, które mają w organizmie korzystne działanie zdrowotne. Okazało się, że część szczepów ma korzystny wpływ na funkcjonowanie 
mózgu. Do wyodrębnienia mikroorganizmów wpływających na działanie układu nerwowego zastosowano nowy termin psychobiotyki. Początkowo badania dotyczyły wpływu stosowania probiotyków na nastrój u osób bez zdiagnozowanych chorób psychicznych. Wyniki wykazały, że u osób suplementujących probiotyki, nastąpiła poprawa samopoczucia. Wówczas podjęto badania $z$ udziałem osób ze zdiagnozowanymi zaburzeniami psychicznymi. Okazało się, że u osób stosujących probiotykoterapię jednocześnie $z$ tradycyjnymi metodami leczenia nastąpiła znaczna poprawa parametrów uznawanych za kryteria diagnostyczne. Dowodzą tego wyniki badania z udziałem osób chorujących na depresję, którym oprócz leków SSRI podawano szczep Lactobacillus plantarum 299v. U tych pacjentów zaobserwowano istotną poprawę funkcji poznawczych, podczas gdy u osób nieprzyjmujących probiotyków efekty terapii były mniej zauważalne. Również w chorobach neurodegeneracyjnych, takich jak choroba Alzheimera, suplementacja szczepami probiotycznymi wywołała pozytywne rezultaty. Na podstawie analizowanego piśmiennictwa, można wnioskować, że szczepy probiotyczne odgrywają niebagatelną rolę $\mathrm{w}$ terapii zaburzeń psychicznych i chorób neurodegeneracyjnych. Pozytywne rezultaty probiotykoterapii świadczą o możliwości wykorzystania wybranych szczepów jako wsparcia stosowanych obecnie konwencjonalnych metod leczenia. Zasadność suplementacji probiotykami w przebiegu chorób ośrodkowego układu nerwowego jest jednak zagadnieniem stosunkowo nowym i wymaga potwierdzenia $\mathrm{w}$ badaniach $z$ udziałem ludzi. W badaniach opisanych $w$ pracy brały udział osoby już zdiagnozowane i leczone metodami standardowymi dla danego schorzenia. W przypadku stosowania farmakoterapii u tych pacjentów nie ma informacji na temat ewentualnego wpływu leków na skład mikrobioty jelitowej.

\section{Konflikt interesów}

Autorki deklarują brak potencjalnych konfliktów interesów.

\section{Piśmiennictwo}

[1] Dinan T.G., Stilling R.M., Stanton C., Cryan J.F.: Collective unconscious: How gut microbes shape human behavior. J. Psychiatr. Res., 2015; 63: 1-9

[2] Milani C., Duranti S., Bottacini F., Casey E., Turroni F., Mahony J., Belzer C., Delgado Palacio S., Arboleya Montes S., Mancabelli L. i wsp.: The first microbial colonizers of the human gut: Composition, activities, and health implications of the infant gut microbiota. Microbiol. Mol. Biol. Rev., 2017; 81: e00036-17

[3] Del Chierico F., Vernocchi P., Petrucca A., Paci P., Fuentes S., Praticò G., Capuani G., Masotti A., Reddel S., Russo A. i wsp.:
Phylogenetic and metabolic tracking of gut microbiota during perinatal development. PLoS One, 2015; 10: e0137347

[4] Underwood M.A., German J.B., Lebrilla C.B., Mills D.A.: Bifidobacterium longum subspecies infantis: Champion colonizer of the infant gut. Pediatr. Res., 2015; 77: 229-235

[5] Avershina E., Storrø O., Øien T., Johnsen R., Pope P., Rudi K.: Major faecal microbiota shifts in composition and diversity with age in a geographically restricted cohort of mothers and their children. FEMS Microbiol. Ecol., 2014; 87: 280-290

[6] Bergström A., Skov T.H., Bahl M.I., Roager H.M., Christensen L.B., Ejlerskov K.T., Mølgaard C., Michaelsen K.F., Licht T.R.: Establishment of intestinal microbiota during early life: A longitudinal, explorative study of a large cohort of Danish infants. Appl. Environ. Microbiol., 2014; 80: 2889-2900

[7] Szewczyk E.M.: Diagnostyka bakteriologiczna. Wydawnictwo Naukowe PWN; Warszawa 2013

[8] Góralska K., Dzikowiec M.: Role of microbiota in maintaining the homeostasis in the human body. Postępy Mikrobiol., 2018; 57: 5-11

[9] Morrison D.J., Preston T.: Formation of short chain fatty acids by the gut microbiota and their impact on human metabolism. Gut Microbes, 2016; 7: 189-200

[10] Binek M.: Znaczenie jelitowych mikrobiontów w utrzymaniu ogólnej homeostazy gospodarza. Post. Mikrobiol., 2015, 54: 207-216

[11] Jandhyala S.M., Talukdar R., Subramanyam C., Vuyyuru H., Sasikala M., Reddy D.N.: Role of the normal gut microbiota. World J. Gastroenterol., 2015; 21: 8787-8803

[12] Petersen C., Round J.L.: Defining dysbiosis and its influence on host immunity and disease. Cell. Microbiol., 2014; 16: 1024-1033

[13] Lange K., Buerger M., Stallmach A., Bruns T.: Effects of antibiotics on gut microbiota. Dig. Dis., 2016; 34: 260-268

[14] Oriach C.S., Robertson R.C., Stanton C., Cryan J.F., Dinan T.G.: Food for thought: The role of nutrition in the microbiota-gut-brain axis. Clin. Nutr. Exp., 2016; 6: 25-38

[15] Sandhu K.V., Sherwin E., Schellekens H., Stanton C., Dinan T.G., Cryan J.F.: Feeding the microbiota-gut-brain axis: Diet, microbiome, and neuropsychiatry. Transl. Res., 2017; 179: 223-244

[16] Rea K., Dinan T.G., Cryan J.F.: The microbiome: A key regulator of stress and neuroinflammation. Neurobiol. Stress, 2016; 4: 23-33

[17] Wang Y., Kasper L.H.: The role of microbiome in central nervous system disorders. Brain. Behav. Immun., 2014; 38: 1-12

[18] de Weerth C.: Do bacteria shape our development? Crosstalk between intestinal microbiota and HPA axis. Neurosci. Biobehav. Rev., 2017; 83: 458-471

[19] Szajewska H.: Probiotyki w Polsce - kiedy, jakie i dlaczego? Gastroenterol. Klin., 2010; 2: 1-9

[20] Sudo N., Chida Y., Aiba Y., Sonoda J., Oyama N., Yu X.N., Kubo C., Koga Y.: Postnatal microbial colonization programs the hypothalamic-pituitary-adrenal system for stress response in mice. J Physiol., 2004; 558: 263-275

[21] Sudo N.: Stress and gut microbiota: Does postnatal microbial colonization programs the hypothalamic-pituitary-adrenal system 
for stress response? Int. Congr. Ser., 2006; 1287: 350-354

[22] Crumeyrolle-Arias M., Jaglin M., Bruneau A., Vancassel S., Cardona A., Daugé V., Naudon L., Rabot S.: Absence of the gut microbiota enhances anxiety-like behavior and neuroendocrine response to acute stress in rats. Psychoneuroendocrinology, 2014; 42: $207-217$

[23] O’Mahony S.M., Clarke G., Borre Y.E., Dinan T.G., Cryan J.F.: Serotonin, tryptophan metabolism and the brain-gut-microbiome axis. Behav. Brain Res., 2015; 277: 32-48

[24] Classifications of Diseases (ICD). https://www.who.int/classifications/icd/en/

[25] Diagnostic and Statistical Manual of Mental Disorders (DSM-5) https://www.psychiatry.org/psychiatrists/practice/dsm

[26] Depression Key facts. https://www.who.int/en/news-room/factsheets/detail/depression

[27] Międzynarodowa Statystyczna Klasyfikacja Chorób i Problemów Zdrowotnych ICD-10 2009. https://www.csioz.gov.pl/fileadmin/ user_upload/Wytyczne/statystyka/icd10tomi_56a8f5a554a18.pdf

[28] Heitzman J.: Zaburzenia depresyjne. Edra Urban \& Partner, Wrocław 2017

[29] Naseribafrouei A., Hestad K., Avershina E., Sekelja M., Linløkken A., Wilson R., Rudi K.: Correlation between the human fecal microbiota and depression. Neurogastroenterol. Motil., 2014; 26: 1155-1162

[30] Foster J.A., Rinaman L., Cryan J.F.: Stress \& the gut-brain axis: Regulation by the microbiome. Neurobiol. Stress, 2017; 7: 124136

[31] Maes M., Kubera M., Leunis J.C.: The gut-brain barrier in major depression: Intestinal mucosal dysfunction with an increased translocation of LPS from gram negative enterobacteria (leaky gut) plays a role in the inflammatory pathophysiology of depression. Neuro Endocrinol. Lett., 2008; 29: 117-124

[32] Jiang H., Ling Z., Zhang Y., Mao H., Ma Z., Yin Y., Wang W., Tang W., Tan Z., Shi J. I wsp.: Altered fecal microbiota composition in patients with major depressive disorder. Brain Behav Immun., 2015; 48: 186-194

[33] Schizophrenia: Key facts. World Health Organization, 2018. https:// www.who.int/en/news-room/fact-sheets/detail/schizophrenia

[34] Jarema M.: Psychiatria. PZWL Wydawnictwo Lekarskie, Warszawa 2016

[35] Nguyen T.T., Kosciolek T., Eyler L.T., Knight R., Jeste D.V.: Overview and systematic review of studies of microbiome in schizophrenia and bipolar disorder. J. Psychiatr. Res., 2018; 99: 50-61

[36] Severance E.G., Gressitt K.L., Stallings C.R., Origoni A.E., Khushalani S., Leweke F.M., Dickerson F.B., Yolken R.H.: Discordant patterns of bacterial translocation markers and implications for innate immune imbalances in schizophrenia. Schizophr. Res., 2013; 148: 130-137

[37] Shen Y., Xu J., Li Z., Huang Y., Yuan Y., Wang J., Zhang M., Hu S., Liang Y.: Analysis of gut microbiota diversity and auxiliary diagnosis as a biomarker in patients with schizophrenia: A crosssectional study. Schizophr. Res., 2018; 197: 470-477
[38] Nguyen T.T., Kosciolek T., Maldonado Y., Daly R.E., Martin A.S., McDonald D., Knight R., Jeste D.V.: Differences in gut microbiome composition between persons with chronic schizophrenia and healthy comparison subjects. Schizophr. Res., 2019; 204: 23-29

[39] Morita C., Tsuji H., Hata T., Gondo M., Takakura S., Kawai K., Yoshihara K., Ogata K., Nomoto K., Miyazaki K., Sudo N.: Gut dysbiosis in patients with anorexia nervosa. PLoS One., 2015; 10: e0145274

[40] Kleiman S.C., Watson H.J., Bulik-Sullivan E.C., Huh E.Y., Tarantino L.M., Bulik C.M., Carroll I.M.: The intestinal microbiota in acute anorexia nervosa and during renourishment: Relationship to depression, anxiety, and eating disorder psychopathology. Psychosom. Med., 2015; 77: 969-981

[41] Lee Y., Park J.Y., Lee E.H., Yang J., Jeong B.R., Kim Y.K., Seoh J.Y., Lee S., Han P.L., Kim E.J.: Rapid assessment of microbiota changes in individuals with autism spectrum disorder using bacteria-derived membrane vesicles in urine. Exp Neurobiol., 2017; 26: 307-317

[42] Coretti L., Paparo L., Riccio M.P., Amato F., Cuomo M., Natale A., Borrelli L., Corrado G., Comegna M., Buommino E. i wsp.: Gut microbiota features in young children with autism spectrum disorders. Front. Microbiol., 2018; 9: 3146

[43] Li Q., Han Y., Dy A.B., Hagerman R.J.: The gut microbiota and autism spectrum disorders. Front. Cell. Neurosci., 2017; 11: 120

[44] Gaweł M., Potulska-Chromik A.: Choroby neurodegeneracyjne: Choroba Alzheimera i Parkinsona. Postępy Nauk Med., 2015; 28: 468-476

[45] Kozubski W., Liberski P.P.: Neurologia. PZWL Wydawnictwo Lekarskie, Warszawa 2006

[46] Vogt N.M., Kerby R.L., Dill-McFarland K.A., Harding S.J., Merluzzi A.P., Johnson S.C., Carlsson C.M., Asthana S., Zetterberg H., Blennow K. i wsp.: Gut microbiome alterations in Alzheimer's disease. Sci Rep., 2017; 7: 13537

[47] Willette A.A., Bendlin B.B., Starks E.J., Birdsill A.C., Johnson S.C., Christian B.T., Okonkwo O.C., La Rue A., Hermann B.P., Koscik R.L. i wsp.: Association of insulin resistance with cerebral glucose uptake in late middle-aged adults at risk for Alzheimer disease. JAMA Neurol., 2015; 72: 1013-1020

[48] Zhan X., Stamova B., Jin L.W., DeCarli C., Phinney B., Sharp F.R.: Gram-negative bacterial molecules associate with Alzheimer disease pathology. Neurology, 2016; 87: 2324-2332

[49] Unger M.M., Spiegel J., Dillmann K.U., Grundmann D., Philippeit H., Bürmann J., Faßbender K., Schwiertz A., Schäfer K.H.: Short chain fatty acids and gut microbiota differ between patients with Parkinson's disease and age-matched controls. Parkinsonism Relat Disord., 2016; 32: 66-72

[50] Hasegawa S., Goto S., Tsuji H., Okuno T., Asahara T., Nomoto K., Shibata A., Fujisawa Y., Minato T., Okamoto A. i wsp.: Intestinal dysbiosis and lowered serum lipopolysaccharide-binding protein in Parkinson's disease. PLoS One, 2015; 10: e0142164

[51] Minato T., Maeda T., Fujisawa Y., Tsuji H., Nomoto K., Ohno K., Hirayama M.: Progression of Parkinson's disease is associated 
with gut dysbiosis: Two-year follow-up study. PLoS One., 2017;

12: e0187307 